\title{
ТЕХНІКО-ЕКОНОМІЧНІ АСПЕКТИ ЗМЕНШЕННЯ ВИКИДІВ ПАРНИКОВИХ ГАЗІВ ШЛЯХОМ РОЗВИТКУ ВІДНОВЛЮВАНИХ ДЖЕРЕЛ ЕНЕРГІЇ
}

\author{
В.А. Хілько, науковий співробітник
}

Інститут відновлюваної енергетики НАН України,

02094, вул. Гната Хоткевича, 20А, м. Київ, Україна.

Метою даної роботи є визначення шляхів зменшення викидів парникових газів. Парникові гази змінюють клімат планети, викликаючи так зване глобальне потепління. Відбувається антропогенний вплив на природу, загроза вимирання біологічних видів та продовольчій безпеці. В роботі розглянуто ринковий механізм кліматичної політики, за допомогою якого можна змінити світовий енергетичний баланс. Сектор енергетики в світі буде в значній мірі екологічно чистим за рахунок широкомасштабного використання відновлюваних джерел енергії. Ринковий механізм - один з основних інструментів кліматичної політики, за допомогою якого держави і компанії можуть продавати або купувати квоти на викиди парникових газів на регіональному, національному або міжнародному ринках. Законом України від 13.07.2016 р. №0105 ратифіковано Паризьку угоду щодо боротьби зі зміною клімату. Окрім міжнародних зобов'язань, запровадження ринку квот на викиди парникових газів передбачені й внутрішніми стратегічними документами Украйни. Згідно з оновленою Енергетичною стратегією України на період до 2035 року оптимізацію структури енергетичного сектора національноі економіки доиільно провадити шляхом збільшення обсягу використання енергетичних джерел з низьким рівнем викидів двоокису вуглецю, збільшення обсягу використання відновлюваних джерел енергії. Виробництво електроенергіі відновлюваними джерелами енергії прогнозується збільшити з доведенням ї̈ частки у загальному первинному постачання енергії у 2035 р. до $25 \%$ у у порівнянні з показником 2015 p. - 4\%. Технічно-досяжний електроенергетичний потенціал відновлюваних джерел енергії України достатній для покриття значної кількості споживання електроенергії в країні. Бібл. 7, табл. 1, рис. 1.

Ключові слова: емісія парникових газів, Паризька угода, вуглечевий ринок, система торгівлі викидами, відновлювані джерела енергії, Національний план дій з відновлюваної енергетики на період до 2020 року.

\section{TECHNICAL AND ECONOMIC ASPECTS GREENHOUSE GAS EMISSION REDUCTION THROUGH THE DEVELOPMENT OF RENEWABLE ENERGY SOURCES}

V. Khilko, research officer

Institute of Renewable Energy of the National Academy of Sciences of Ukraine, 02094, 20A Hnata Khotkevycha St., Kyiv, Ukraine.

The aim of this work is to identify ways to reduce greenhouse gas emissions. Greenhouse gases change the climate of the planet, causing the so-called global warming. There is anthropogenic impact on nature, the threat of extinction of biological species and food security. The paper considers the market mechanism of climate policy, with which is possible to change the global energy balance. The global energy sector will be largely environmentally friendly through the widespread use of renewable energy sources. The market mechanism is one of the main instruments of climate policy, with the help of which states and companies can sell or buy quotas for greenhouse gas emissions in the regional, national or international markets. The Law of Ukraine of July 13, 2016 No. 0105 ratified the Paris Agreement on Climate Change. In addition to international obligations, the introduction of a market for quotas for greenhouse gas emissions is also provided for by internal strategic documents of Ukraine. According to the updated Energy Strategy of Ukraine for the period until 2035, it is advisable to optimize the structure of the energy sector of the national economy by increasing the use of energy sources with low carbon dioxide emissions, and increasing the use of renewable energy sources. Electricity production by renewable energy sources is projected to increase with bringing its share in the total primary energy supply in 2035 to $25 \%$, compared to 2015 - 4\%. The technically achievable electricity potential of Ukraine's renewable energy sources is sufficient to cover significant amount of the country's electricity consumption. Ref. 7, tab. 1, fig. 1 .

Keywords: greenhouse gas emission, Paris agreement, carbon market, emissions trading system, renewable energy sources, National Renewable Energy Action Plan up to 2020 year.

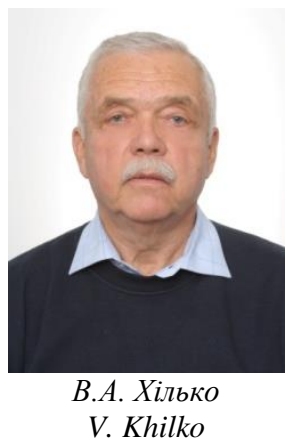

Відомості про автора: науковий співробітник Інституту відновлюваної енергетики НАН України.

Освіта: Київський технологічний інститут легкої промисловості, факультет електротехніки та автоматики

Наукова сфера: відновлювана енергетика, економічний аналіз, електропостачання.

Публікації: 35 публікації.

ORCID: 0000-0001-6348-2578

Контакти: тел./факс +38-044-206-28-09

e-mail: renewable@ukr.net
Author information: Research officer of the Institute of Renewable Energy of the NAS of Ukraine.

Education: Kyiv's Technological Institute of Light Industry on Electrical Engineering and Automatics Faculty.

Research area: renewable energy, economic analysis, power supply.

Publications: 35 publications.

ORCID: 0000-0001-6348-2578

Contacts: tel/fax: +38-044-206-28-09

e-mail: renewable@ukr.net

(C) В.А. Хілько, 2019 
Перелік використаних позначень та скорочень: ООН - Організація Об'єднаних Націй;

ВДЕ - відновлювані джерела енергії;

СТВ - система торгівлі викидами;

ССТВ - Свропейська система торгівлі викидами;

Походження парникових газів. Парникові гази викликані діяльністю людини і виникають при спалюванні або переробці викопного палива, спалюванні біомаси тощо. Найбільш сильний вплив на клімат планети надають наступні види парникових газів:

- Діоксид вуглецю $\left(\mathrm{CO}_{2}\right)$ - головне джерело кліматичних змін, на частку якого припадає близько 64\% глобального потепління. Джерелами викиду діоксиду вуглецю (вуглекислого газу) в атмосферу $\epsilon$ виробництво, транспортування, переробка та споживання викопного палива (86\%), вирубка тропічних лісів, спалювання біомаси $(12 \%)$, та інші джерела (2\%), наприклад, виробництво цементу та окислення моноксиду вуглецю.

- Метан $\left(\mathrm{CH}_{4}\right)$. На частку метану приходиться приблизно 20\% глобального потепління.

- Закис азоту $\left(\mathrm{N}_{2} \mathrm{O}\right)$. На нього припадає близько 6\% глобального потепління.

Механізм впливу парникових газів на клімат планети наступний. Земля перетворює енергію падаючого на неї видимого сонячного світла в інфрачервоне випромінювання, що прямує від Землі в космос. Парникові гази ускладнюють цей процес, поглинаючи інфрачервоне випромінювання, i утримуючи в атмосфері планети спрямовану в космос енергію. Тому отримане надлишкове тепло залишається на планеті. Таким чином парникові гази надають шкідливу дію на повітряне середовище, викликаючи підвищення середньої температури кліматичної системи нашої планети, так зване глобальне потепління.

До наслідків потепління відносяться: збільшення частоти екстремальних погодних явищ, включаючи хвилі спеки, посухи та зливи; окислення океану; вимирання біологічних видів через зміну температурного режиму. До важливих наслідків потепління також відноситься: загроза продовольчій безпеці через негативний вплив на врожайність, всихання лісів внаслідок масового поширення шкідників i втрата місць проживання людей через підвищення рівня моря.

На 21-ій Конференції Організації Об'єднаних Націй $(\mathrm{OOH})$ у грудні 2015 р. в Парижі було прийнято глобальну угоду 3 протидії зміні клімату на 2021 - 2030 рр. - Паризьку угоду. Цією Угодою пропонується урядам усіх країн докладати максимальних зусиль щодо утримання приросту глобальної середньої температури
MEA - Міжнародне енергетичне агентство;

АЕC - атомна електростанція;

ТЕС - теплова електростанція;

МЗВ - система моніторингу, звітності, верифікації.

планети «набагато нижче $2^{\circ} \mathrm{C}$ понад доіндустріальних рівнів» і докладанні зусиль для обмеження зростання температури до рівня $1,5^{\circ} \mathrm{C}$.

Генеральний секретар $\mathrm{OOH}$ Антоніу Гутерріш зустрічався в місті Біарріц (Франція) 3 лідерами G7 3 метою мобілізації дій перед Самітом 2019 p. зі зміни клімату, котрий відбудеться у вересні в Нью-Йорку [1].

На зустрічі Антоніу Гутерріш оголосив про надзвичайну кліматичну ситуацію: температура б'є всі рекорди, а масштабні пожежі в ряді регіонів спричинили за два поточних місяці 129 Мт додаткових викидів вуглекислого газу. Лише у Гренландії у липні поточного року сталося танення 179 млрд. тонн льодовиків. За даними Всесвітньої метеорологічної організації ООН 2015-2019 рр. є найспекотнішими з коли-небудь зареєстрованих років і мають історично високі концентрації $\mathrm{CO}_{2}$ в атмосфері землі. Глава $\mathrm{OOH}$ назвав проблему зміни клімату «головним питанням нашого часу» і закликав вжити заходів для зменшення негативних наслідків парникового ефекту.

Заходи щодо зниження емісії парникових газів. Для досягнення стабілізації температурного режиму Землі необхідно вдвічі знизити викиди парникових газів в атмосферу, що може бути зроблено винятково шляхом кардинальної зміни світового енергетичного балансу.

Ринковий механізм - один 3 основних інструментів кліматичної політики, за допомогою якого держави і компанії можуть продавати або купувати квоти на викиди парникових газів на регіональному, національному або міжнародному ринках. Один 3 найважливіших результатів створення вуглецевого ринку та систем квотування викидів є встановлення ціни на викиди парникових газів, що підвищує витрати, пов'язані 3 діяльністю, яка спричиняє забруднення. В результаті знижується конкурентоспроможність вуглецемістких галузей промисловості у порівнянні з екологічно чистими технологіями.

Два види ринкових інструментів можуть забезпечити встановлення ціни на викиди: торгівля квотами на викиди та податок на викиди в атмосферу. Ключова різниця полягає в тому, що при податку на викиди парникових газів уряд встановлює ціну та дозволяє ринку визначати 
кількість викидів парникових газів. При торгівлі квотами на викиди, навпаки, уряд встановлює обмеження по кількості викидів та дозволяє ринку визначати ціну, що 3 точки зору обмеження викидів парникових газів найбільш прийнятно.

Заміщення традиційних технологій в галузі енергетики відновлюваними джерелами енергії (ВДЕ) знижує емісію парникових газів. Використання ВДЕ (Сонця, вітру, біомаси, геотермальної енергії, річок) також забезпечує:

- енергетичну незалежність країн або істотне зниження залежності від імпорту енергоносіїв;

- перспективи розвитку ринків збуту наукоємного обладнання та диверсифікації діяльності промислового комплексу країни;

- невичерпність ресурсів енергії і відсутність можливості їх приватизації або захоплення іншими країнами (на відміну від родовищ нафти і газу);

- екологічну чистоту енергетичної галузі.

Станом на кінець 2018 року у світі 169 країн або окремих регіонів на державному рівні визначили політичні цілі щодо розвитку відновлюваної енергетики, та ще 398 країн (штатів, провінцій) - по заходах з стимулювання розвитку ВДЕ [2].

Система торгівлі викидами. Сутність системи торгівлі викидами (СТВ) полягає в тому, що в рамках обмеження на викиди компанії отримують, або купують дозволи на викиди, які являються ринковими елементами. В кінці кожного року компанія повинна мати достатню кількість дозволів, щоб покрити дозволені обсяги викидів, в іншому випадку накладаються штрафи. Якщо компанія скоротила викиди, вона може зберігати надлишкові дозволи для покриття своїх майбутніх потреб, або продавати їх іншій компанії, якій не вистарчає обсягу дозволів.

Теоретично ціна квот на конкретному ринку відображає граничні витрати на викиди тонни $\mathrm{CO}_{2}$, або еквівалента парникових газів. Рівень поточних цін на вуглецевих ринках світу надано в таблиці 1.

Таблиця 1. Поточна ціна квот на викиди діоксиду вуглецю у 2018 році.

Table 1. Current price of carbon dioxide emission quotas in 2018.

\begin{tabular}{|l|l|l|}
\hline \multicolumn{1}{|c|}{ Назва ринку } & \multicolumn{1}{|c|}{ Ціна за т СО2 } & \multicolumn{1}{c|}{ Місцеве джерело ціни } \\
\hline Каліфорнія - Квебек & USD 14.61 & $\begin{array}{l}\text { Каліфорнійський рада з повітряних ресурсів } \\
\text { https://www.arb.ca.gov/cc/capandtrade/auction/feb- } \\
\text { 2018/summary results report.pdf }\end{array}$ \\
\hline Пілотні проекти СТВ Китаю & USD 7.50 - USD 1.36 & Європейська енергетична біржа \\
\hline СТВ ЄC & USD 17.30 (EUR 13.99) & Європейська енергетична біржа \\
\hline Корея & USD 20.66 & Корейська біржа \\
\hline Нова Зеландія & USD 15.58 & Акредитований учасник ринку «ОМF CommTrade» \\
\hline Онтаріо & USD 14.60 & $\begin{array}{l}\text { Міністерство навколишнього середовища і зміни клімату } \\
\text { провінції Онтаріо. }\end{array}$ \\
\hline RGGI & RGGI, Іпс. - некомерційна корпорація 9 штатів США \\
\hline Швейцарія & USD 3.79 & Швейцарський реєстр системи торгівлі викидами \\
\hline
\end{tabular}

Джерело: International Carbon Action Partnership (ICAP)

У 2016 році дохід від торгівлі квотами в усьому світі склав близько 30 млрд. доларів США. СТВ діє в країнах, які виробляють майже половину світового валового внутрішнього продукту і надають понад $15 \%$ світових викидів парникових газів [3].

За рахунок доходів від продаж квот на викиди були профінансовані додаткові програми по боротьбі зі зміною клімату, 3 розвитку відновлюваних джерел енергії i надання матеріальної підтримки малозабезпеченим групам населення.

Принципи роботи європейської системи торгівлі викидами. Згідно Директиви 2003/87/СС з 1 січня 2005 року усі об'єкти, що виконують діяльність в енергетичному секторі, виробництві та обробці заліза та сталі, видобувній промисловості, виробництві деревини, паперу i картону та здійснюють викиди парникових газів, які пов'язані 3 виробничою діяльністю, повинні мати дозволи, видані компетентними органами.

У відповідності до умов функціонування європейської системи торгівлі викидами (ССТВ), компетентний орган визначає загальний обсяг викидів, які можна здійснювати в країнах $\mathrm{CC}$ протягом певного часу, а потім ці викиди розподіляються між забруднювачами учасниками ринку. Сьогодні ЄСТВ працює в 31 країні (всі 28 країн $Є С$ та Ісландія, Ліхтенштейн 
та Норвегія). ЄСТВ обмежує викиди від більш ніж 11000 установок, що використовують екологічно шкідливі технології.

Для енергетичних установок в ЕСТВ встановлюється загальний граничний обсяг викидів, на який випускаються квоти. Частина цих квот розподіляється безкоштовно між відповідними енергетичними установками, а частина продається. Якщо енергоустановка не перевищує кількість отриманих безкоштовних квот за допомогою, наприклад, заходів 3 енергоефективності, різниця між фактичними викидами i отриманими квотами може продаватися. Якщо підприємство не може «вкластися» в надані йому квоти, у нього $\epsilon$ можливість придбати додаткові квоти на ринку.

Дозволи на викиди парникових газів, які не надаються безкоштовно, продаються через аукціони. Аукціони є відкритим способом розподілення дозволів, які дозволяють учасникам ринку отримати дозволи на викиди за ринковою ціною. У секторі енергетики ЄС з 2013 року всі дозволи розподіляються на аукціонах. Сдиним винятком $є$ надання безкоштовних дозволів для модернізації енергетичного сектору в деяких країнах.

Згідно прийнятим в ЄСТВ умовам, якщо дозволи на викиди парникових газів продаються на аукціонах, це створює джерело доходу. Цей дохід має використовуватися на заходи по зниженню викидів парникових газів, в тому числі для розвитку відновлюваної енергетики.

Контроль за системою торгівлі викидів в кожній країні здійснює уповноважений владою орган, яким видаються відповідні квоти на викиди парникових газів та здійснюється контроль за їх реалізацією.

Реалізація ССТВ була розділена на окремі періоди (фази). Перша фаза ЕСТВ (2005-2007 pp.) розглядалася як пілотна. Основною їі метою було забезпечення підготовки країн-членів СС до ефективного виконання ї зобов'язань за Кіотським протоколом. Видавалися безоплатно 95\% дозвільних одиниць.

На другій фазі ССТВ (2008-2012 рр.) 90\% дозвільних одиниць видавалися безоплатно. Підприємствам було дозволено використовувати для виконання своїх зобов'язань одиниці скорочення викидів, які створені в рамках проектів спільного впровадження. 32012 року ССТВ була розширена шляхом включення до неї авіації.

Основні відмінності третьої фази (2013-
2020 рр.) полягають в тому, що:

- Замість попередньої системи національних обмежень викидів, застосовується єдиний підхід загальноєвропейського обмеження щодо викидів парникових газів.

- За загальним правилом дозволи на викиди розподіляються на аукціонах (замість безкоштовного розподілу на перших двох фазах) і узгоджені правила розподілу застосовуються до дозволів, які все ще видаються безкоштовно.

- Більше видів парникових газів включено до ECTB.

- 300 млн. дозволів виділено в резерві для фінансування розгортання інноваційних технологій відновлюваної енергії та уловлювання та зберігання вуглецю.

Наразі розробляються правила ЄСТВ для четвертої фази, які стосуються періоду починаючи 32021 року. Окрім сприяння скороченню викидів парникових газів за рахунок економії, ЄСТВ буде значно інтенсивніше стимулювати інновації та сприяти використанню технологій відновлюваної енергетики.

Зменшення викидів парникових газів шляхом впровадження ВДЕ. Сектор електроенергетики знаходиться в центрі уваги багатьох зобов язань за Паризькою угодою. Прогнозні розробки Міжнародного енергетикного агентства (MEA), що найбільш визнаються в світі, містять опрацьовування декількох основних сценаріїв розвитку енергетики світу.

Сценарієм нової політики MEA прогнозується, що до 2040 р. частка відновлюваних джерел енергії в споживанні електроенергії зросте до двох третин у 2040 році, у порівнянні 3 однією чвертю сьогодні [4]. Більшість таких потужностей за цей період стануть конкурентоспроможними без будь-яких субсидій. Розвиток у сфері промисловості приведе до зниження питомих витрат: очікується, що до 2040 р. в сонячній електроенергетиці середні питомі витрати скоротяться на 50\%, а в наземній вітровій електроенергетиці - на $20 \%$.

Варто зауважити, що наразі вперше в історії енергетики приріст нових потужностей ВДЕ перевищив аналогічний показник традиційної генерації, що $є$ свідченням підвищення конкурентоспроможності ВДЕ серед первинних джерел енергії. Динаміка зростання світової потужності ВДЕ, включаючи показники по окремим джерелам, надана на рис. 1. 


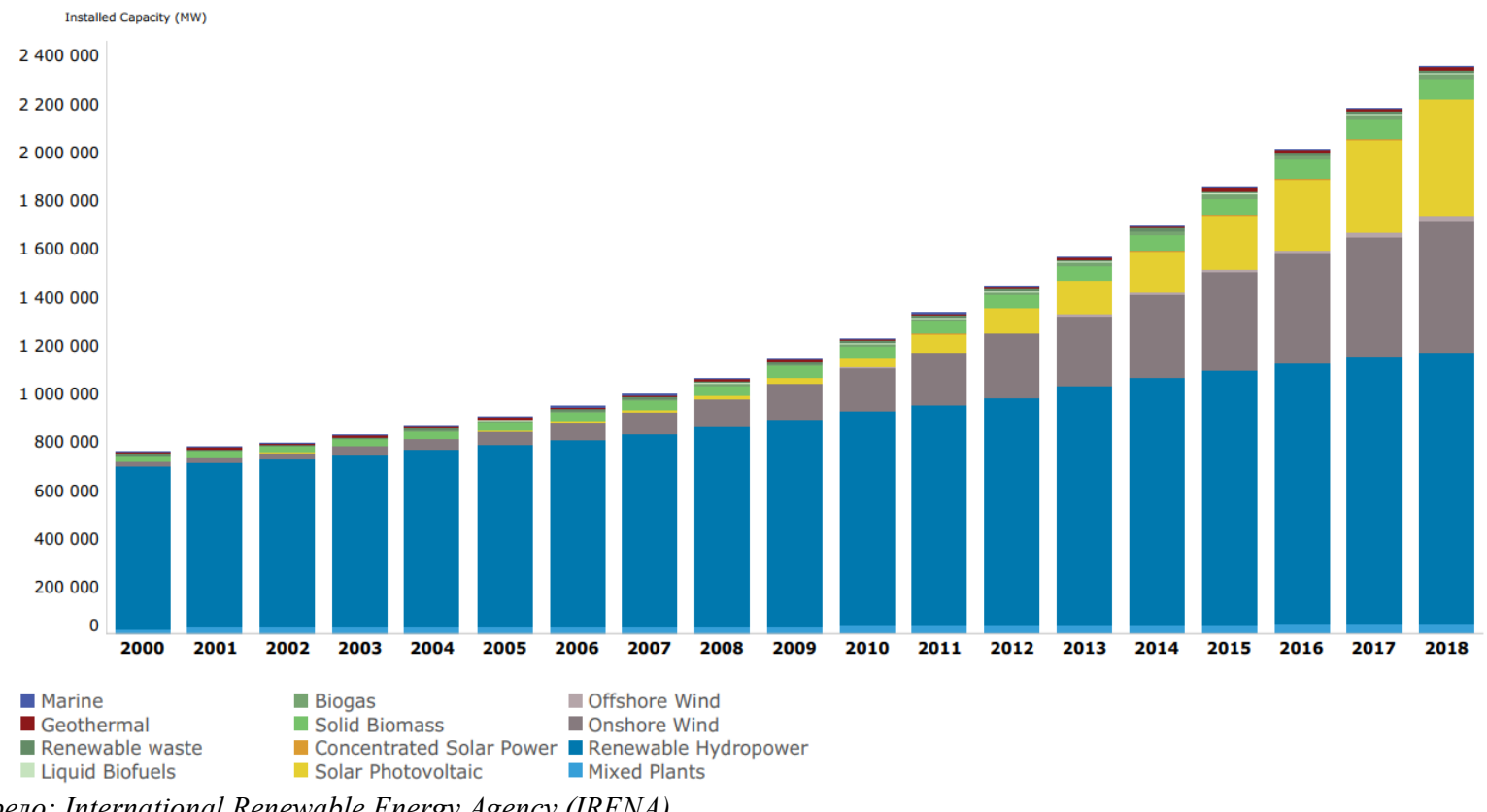

Джерело: International Renewable Energy Agency (IRENA)

Рис. 1. Динаміка зростання потужностей ВДЕ у світі.

Fig. 1. Dynamics of RES capacity growth in the world.

Відновлювані джерела енергії, на відміну від викопних видів палива, $є$ невичерпними:

- фотоелектрична енергетика, у середньому на кожний квадратний метр планети припадає 1700 кВт·год сонячної енергії щорічно. Для Європи цей показник становить близько 1000 кВт·год на рік, на Середньому Сході він досягає 1800 кВт·год.

- вітрова енергія, запаси якої в основному рівномірно розподілено по всіх континентах. Вітрові установки можна успішно експлуатувати не лише в прибережних районах, але й у країнах, які не мають узбереж, включаючи такі регіони, як Центральна Східна Європа, Центральна Північна й Центральна Південна Америка, Центральна Азія.

- енергія біомаси, діапазон кінцевого застосування якої широкий: опалення, виробництво електроенергії й палива для транспортних засобів. Як транспортне паливо все ширше використовується біодизель, який виробляється з різних сільськогосподарських культур.

- геотермальна енергія в багатьох регіонах, до яких відносяться західна частина США, Західна й Центральна Східна Європа, Ісландія, Азія й Нова Зеландія.

- гідроенергія, яка становить близько п'ятої частини всієї електроенергії у світі та виробляється на гідроелектростанціях. Разом з тим, відмічається, що великі гребельні гідроелектростанції та водосховища в окремих регіонах негативно впливають на навколишнє середовище.
За ценарієм MEA 450 прогнозується, що сектор електроенергетики в значній мірі буде декарбонізований: середні питомі викиди при генерації електроенергії в 2040 р. скоротяться до 80 г $\mathrm{CO}_{2} / \mathrm{\kappa B}$ Т.год, порівняно 3515 г $\mathrm{CO}_{2} /$ кВт・год сьогодні [5].

Основні напрями досягнення цілей щодо розвитку ВДЕ затверджено у Директиві 2009/28/ЄС. При цьому визнано доцільним використання декількох типів економічних інструментів: зеленого тарифу, зеленої премії до тарифу та зелених сертифікатів.

У Німеччині в першому півріччі 2019 року із відновлюваних джерел енергії вперше в країні вироблено більше електроенергії, ніж на АEC та вугільних ТЕС разом узятих. Про це повідомляє видання Power Technology [6] 3 посиланням на звіт інституту Фраунгофера (Німеччина). При цьому збільшення виробництва електроенергії із відновлюваних джерел та зростання цін на квоти щодо викидів $\mathrm{CO}_{2}$ сприяли скороченню викидів вуглекислого газу під час генерації електроенергії. Так, у першій половині 2019 року німецький енергетичний сектор знизив викиди $\mathrm{CO}_{2}$ на 20 мільйонів тонн, у порівнянні 3 аналогічним періодом 2018 року.

Організація в Україні торгівлі квотами на викиди та сприяння скороченню викидів шляхом розвитку ВДЕ. Законом України від 13.07.2016 р. №0105 ратифіковано Паризьку угоду щодо боротьби зі зміною клімату. Окрім 
міжнародних зобов'язань, запровадження ринку квот на викиди парникових газів передбачені й внутрішніми стратегічними документами України.

Розпорядженням КМУ № 371-p від 15.04.2015 схвалено план імплементації Директиви про СТВ. Імплементація Директиви про СТВ передбачає: розроблення національного плану розподілу квот на викиди; запровадження дозвільної системи на викиди парникових газів; створення на національному рівні системи продажу дозвільних одиниць на викиди парникових газів, створення системи моніторингу, звітності, верифікації і належного впровадження (МЗВ), а також процедури консультацій з громадськістю.

Згідно 3 оновленою Енергетичною стратегією України на період до 2035 року оптимізацію структури енергетичного сектора національної економіки доцільно провадити шляхом збільшення обсягу використання енергетичних джерел 3 низьким рівнем викидів двоокису вуглецю, збільшення обсягу використання відновлюваних джерел енергії. Виробництво електроенергії відновлюваними джерелами енергії прогнозується збільшити 3 доведенням ऑiі частки у загальному первинному постачання енергіï у 2035 р. до $25 \%$, у порівнянні з показником 2015 р. - 4\%.

У СТВ України за всіма показниками може потрапити близько 500 установок з річним обігом викидів парникових газів 200 млн. тонн $\mathrm{CO}_{2}$-екв. Найуразливішим сектором до виплат за викиди $\mathrm{CO}_{2}$ буде теплова енергетика (194 млн. т $\mathrm{CO}_{2}$-екв викидів в 2014 році), а також металургійні, нафтові, цементні та інші вуглецевоємні підприємства.

Крім встановлення чіткого обмеження на викиди, система торгівлі квотами в Україні на викиди вуглецю формує для всіх підприємств країни стимули для інвестицій в ті галузі, де скорочення викидів найімовірніше. Кошти від продажу квот на аукціонах потрапляють до державного бюджету i можуть бути спрямовані на фінансування проектів 3 відновлюваної енергетики.

Верховною радою України 28 лютого 2019 р. прийнято в першому читанні проект Закону України «Про засади моніторингу, звітності та верифікації викидів парникових газів». Наразі текст законопроекту підготовлено до другого читання.

На виконання Національного плану дій 3 відновлюваної енергетики на період до 2020 року Державним агентством 3 енергоефективності та енергозбереження України разом 3 Інститутом відновлюваної енергетики НАН України та профільними асоціаціями розроблено Дорожню карту розвитку відновлюваної енергетики України на період до 2020 року щодо сприяння залученню інвестицій у розвиток сфери відновлюваної енергетики України.

За даними міжнародного агентства 3 відновлюваної енергетики IRENA [7] річний технічно досяжний енергетичний потенціал відновлюваних джерел енергії України становить 68,9 млн. т нафтового еквівалента. Це еквівалентно 98 млн. т умовного палива.

Технічно-досяжний електроенергетичний потенціал відновлюваних джерел енергії України достатній для покриття значної кількості споживання електроенергії в країні.

Висновки. Парникові гази шкідливо діють на повітряне середовище планети, викликаючи підвищення середньої температури їі кліматичної системи. Відбувається антропогенний вплив на природу, загроза вимирання біологічних видів, загроза продовольчій безпеці, втрата місць проживання людей через підвищення рівня моря.

Система торгівлі квотами на викиди парникових газів знижує конкурентоспроможність вуглецемістких галузей промисловості у порівнянні з екологічно чистими технологіями.

Система торгівлі квотами на викиди парникових газів сформує в Україні стимули для інвестицій в галузь відновлюваної енергетики.

Технічно-досяжний електроенергетичний потенціал відновлюваних джерел енергії України достатній для покриття значної кількості споживання електроенергії в країні.

Україна виконує взяті міжнародні зобов'язання щодо скорочення викидів парникових газів та вносить відповідні зміни в законодавство.

3 метою впровадження в Україні системи торгівлі квотами на викиди парникових газів Верховною радою України прийнято в першому читанні проект Закону України «Про засади моніторингу, звітності та верифікації викидів парникових газів».

Дана стаття підготовлена в рамках виконання проекту цільових програм наукових досліджень НАН України «Енергодім» (КПКВК 6541230).

1. UN chief appeals to G7 leaders for «strong commitment» and political will to tackle climate emergency. [Електронний pecypc]. URL: https://news.un.org/en/story/2019/08/1044921.

2. REN21. Renewables 2018. Global Status Report. [Електронний ресурc].URL: https://www.ren21.net.

3. Международное партнерство по воздействию углерода. Торговля выбросами парниковых газов по всему 
миру. Краткий обзор. Ежегодный отчет. 2017. [Електронний pecypc]. URL: https://icapcarbonaction.com/ru/.

4. World Energy Outlook 2018. New Policies Scenario. [Електронний ресурс]. https://www.iea.org/weo2018/scenarios/

5. НПЦР ОЕС України. Огляд реалізації основних положень Кіотського протоколу до Рамкової Конвенції ООН про зміну клімату та зобов'язання країн-членів ОЕСР i Євросоюзу щодо виконання рекомендацій Паризької Конференції. Київ. 2017. 107 с. [Електронний ресурс]. URL: https://ua.energy/wp-content/uploads/2017/05/3.-

Osn_polozh_SOR21.pdf.

6. Power Technology. Most electricity in Germany comes from renewable sources. [Електронний pecypc]. URL: https://www.power-technology.com/news/most-electricity-ingermany-comes-from-renewable-sources/.

7. International Renewable Energy Agency. REmap 2030: Renewable Energy Prospects for Ukraine. [Електронний pecypc]. URL: https://www.irena.org/publications/ 2015/Apr/Renewable-Energy-Prospects-for-Ukraine.

\section{REFERENCES}

1. UN chief appeals to G7 leaders for «strong commitment» and political will to tackle climate emergency. [Electronic resource]. URL: https://news.un.org/en/story/2019/08/1044921. [in English].

2. REN21. Renewables 2018. Global Status Report. [Electronic resource].URL: https://www.ren21.net. [in English].

3. Mezhdunarodnoye partnerstvo po proizvodstvu ugleroda. Torgovlya vybrosami parnikovykh gazov po vsemu miru. [International Carbon Action Partnership. Greenhouse gas trading worldwide]. Short review. Annual report. 2017 [Electronic resource]. URL: https://icapcarbonaction.com/ru/. [in Russian].

4. World Energy Outlook 2018. New Policies Scenario. [Electronic 4. World Energy Outlook 2018 .
resource]. URL: https://www.iea.org/weo2018/scenarios/.

5. NPTSR OYES Ukraini. Obzor osnovnykh polozheniy Protokola k Ramochnoy konventsii OON o statuse kandidata $\mathrm{v}$ chleny krayev-chlenov OESR i yego sovetskoy delegatsii v Parizhe. [NESPC at United Energy System of Ukraine. An overview of the implementation of the main provisions of the Kyoto Protocol to the UN Framework Convention on Climate Change and the commitment of OECD and EU member states to implement the recommendations of the Paris Conference]. Kiev. 2017. $107 \mathrm{p}$. [Electronic resource]. URL: https://ua.energy/wpcontent/uploads/2017/05/3.-Osn_polozh_SOR21.pdf. [in Ukrainian]

6. Power Technology. Most electricity in Germany comes from renewable sources. [Electronic resource]. URL https://www.power-technology.com/news/most-electricity-ingermany-comes-from-renewable-sources/.

7. International Renewable Energy Agency. REmap 2030: Renewable Energy Prospects for Ukraine. [Electronic resource] URL: https://www.irena.org/publications/2015/Apr/RenewableEnergy-Prospects-for-Ukraine.
ТЕХНИКО-ЭКОНОМИЧЕСКИЕ АСПЕКТЫ УМЕНЫШЕНИЯ ВЫБРОСОВ ПАРНИКОВЫХ ГАЗОВ ПУТЕМ РАЗВИТИЯ ВОЗОБНОВЛЯЕМЫХ ИСТОЧНИКОВ ЭНЕРГИИ

\section{В.А. Хилько, научный сотрудник}

Институт возобновляемой энергетики НАН Украины, 02094, ул. Гната Хоткевича, 20-А, г. Киев, Украина.

Целью данной работы является определение путей уменьшения выбросов парниковых газов. Парниковые газы изменяют климат планеты, вызывая так называемое глобальное потепление. Происходит антропогенное воздействие на природу, угроза вымирания биологических видов и продовольственной безопасности. В работе рассмотрен рыночный механизм климатической политики, с помощью которого можно изменить мировой энерге-тический баланс. Сектор энергетики в мире будет в значительной степени экологически чистым за счет широкомасштабного использования возобновляемых источников энергии. Рыночный механизм - один из основных инструментов климатической политики, с помощью которого государства и компании могут продавать или покупать квоть на выбросы парниковых газов на регионально, национальном или международном рынках. Законом Украины от 13.07.2016 2. №0105 ратифицировано Парижское согламение по борьбе с изменением климата. Кроме международных обязательств, введение рынка квот на выбросы парниковых газов предусмотрены и внутренними стратегическими документами Украины. Согласно обновленной Энергетической стратегии Украины на период до 2035 года оптимизацию структуры энергетического сектора национальной экономики целесообразно проводить путем увеличения объема использования энергетических источников с низким уровнем выбросов двуокиси углерода, увеличение объема использования возобновляемых источников энергии. Производство электроэнергии возобновляемыми источниками энергии прогнозируется увеличить с доведением ее доли в общем первичной поставке энергии в 2035 до 25\%, по сравнению $c$ показателем 2015 - 4\%. Технически достижимый электроэнергетический потенциал возобновляемых источников энергии Украины достаточен для покрытия значительного количества потребления электроэнергии в стране. Библ. 7, табл. 1, рис. 1.

Ключевые слова: эмиссия парниковых газов, Парижское соглашение, углеродный рынок, система торговли выбросами, возобновляемые источники энергии, Национальный план действий по возобновляемой энергетике на период до 2020 года. 